\title{
The Approach of Czech Business Entities to the Promotion and Application of the Corporate Social Responsibility
}

\author{
Pavla VRABCOVÁ ${ }^{1 *}$ and Hana URBANCOVÁ ${ }^{2}$ \\ 1 Czech University of Life Sciences Prague, Prague, Czech Republic; vrabcovapavla@gmail.com \\ 2 University of Economics and Management, Prague, Czech Republic; hana.urbancova@vsem.cz \\ * Corresponding author: vrabcovapavla@gmail.com
}

\begin{abstract}
The importance of responsible business lies in the reflection of the basic values of the company. Responsible business is important for large or small businesses, which can improve their economic, environmental, and social characteristics in the short and long term through innovative products and services, new skills, and stakeholder involvement. It includes the commitment of the organization to develop its economic activities effectively and responsibly towards society and the environment, taking into account the interests of all stakeholders. The aim of the article is to identify the approaches of Czech business entities to the promotion of the concept of social responsibility in selected organizations $(n=179)$. Data were obtained through questionnaire data collection during June to December 2020. Chi-square tests were applied to determine the dependencies. The results showed that most of the addressed organizations focus on the assessment of processes and projects regarding their economic, environmental, and social aspects and impacts (41.3\%), while the approach of business entities to promoting the concept of social responsibility is not influenced by the sector, size, type or ownership share of the organization.
\end{abstract}

Keywords: competitiveness; corporate social responsibility; the Czech Republic; sustainable development

\section{JEL Classification: M10; M14}

\section{Introduction}

The primary theme of sustainable development in the 19th century was the relationship between man and nature and human settlement and the landscape. The beginnings of the idea of corporate social responsibility (CSR) have been appearing in society since the 1930s, and the experience of a deteriorating environment (Cancino et al., 2018), catastrophes (Yadlapalli et al., 2020) and the global energy crisis. Some authors (Kolk \& Van Tulder, 2010) consider CSR to be a key contribution of society to sustainable development. CSR initiatives are often closely linked to business sustainability initiatives (Ahi \& Searcy, 2013), and some authors consider these terms to be synonymous (Van Marrewijk, 2003).

Social responsibility represents the entrepreneur's obligation to carry out such procedures and make such decisions that are desirable from the point of view of the company's values. It is the voluntary integration of social and environmental aspects into everyday corporate operations and interactions with corporate stakeholders (EU, 2001). It is also possible to state, 
that social responsibility is further applied in management fields such as sustainable revenue management, etc. (Petříček et al., 2020). According to the European Commission, CSR is described as "to create favorable conditions for sustainable growth, responsible business behavior and durable employment generation in the medium and long term" (EC, 2011). A characteristic feature of the above definitions is universality (Charitoudi et al., 2011).

In 2011, the Commission adopted a renewed strategy for CSR. The strategy combines horizontal approaches to promote CSR with specific approaches. Commission published document called Corporate Social Responsibility, Responsible Business Conduct, and Business \& Human Rights: Overview of Progress which gives an overview of the progress progress implementing CSR. CSR is not regulated in the Czech Republic; it is a voluntary instrument managed by the Ministry of Industry and Trade. The support of the concept of social responsibility in the Czech Republic is not solved centrally by the state; there is no formal support for the concept of corporate social responsibility.

A number of analyzes of CSR definitions have been published (e.g. Dahlsrud (2008) who shows that most definitions are largely identical). However, most definitions focus on addressing the needs of key stakeholders in the long term. Key characteristics include (Ahi \& Searcy, 2013; Cancino et al., 2018; Ciccullo et al., 2018; Fortunati et al., 2020): economic pillar, social pillar, and environmental pillar. In addition to these three characteristics, the authors Sarkar and Searcy (2016) add stakeholder focus, volunteer focus, longevity, and resilience focus. However, for example, Bansal et al. (2015) state that CSR can be accepted as a short-term - tactical orientation of the company, or as a long-term - strategic orientation.

In the context of a large number of definitions, CSR has been described as a chameleon concept (Gond \& Moon, 2011; Sarkar \& Searcy, 2016). Authors Sarkar and Searcy (2016) agree that the fact that so many definitions of CSR have been proposed makes it even difficult to develop a theoretical concept, which hinders the development and implementation of tactics and strategies to promote CSR goals. In their research, they concluded that the peer-reviewed journals, books, and nonacademic publications examined yielded a total of 110 definitions of the term CSR. Or, e.g., Dahlsrud (2008) focused on the analysis of 37 definitions. The analysis of the definitions according to Sarkar and Searcy (2016) shows following definition: "CSR implies that firms must foremost assume their core economic responsibility and voluntarily go beyond legal minimums so that they are ethical in all of their activities and that they take into account the impact of their actions on stakeholders in society, while simultaneously contributing to global sustainability."

The authors (e.g. Burke et al., 1996; Gallardo-Vázquez \& Turyakira et al., 2014) mention the benefits of implementing CSR: increased profits through reduced costs and increased productivity, better availability of capital (Schiebel \& Pöchtrager, 2003), improved image (Jorge et al., 2015), achieving higher customer loyalty (Ali et al., 2010; Camacho \& Fernandez, 2018), better opportunities in recruiting and retaining quality employees (Mandl \& Door, 2007; Jenkins, 2009), mitigation legal measures, risk reduction and risk management costs, increased performance (Bernal-Conesa et al., 2017; Hung et al., 2019), maintaining competitiveness (Porter \& Kramer, 2006; Marín et al., 2012; Boulouta \& Pitelis, 2014; Gallardo-Vázquez \& Sanchez-Hernandez, 2014; Jorge et al., 2015) and improving the learning and innovation cycle (Vilanova et al., 2009). CSR activities can be one of several criteria on the basis of which the 
customer chooses the company from which to purchase services or products. In contrast, Marin et al. (2017) did not show in their research the direct impact of CSR on competitiveness, but it turned out that innovation and investment affect the impact of CSR on competitiveness indirectly but significantly (their results show the overall intermediary effect of innovation and investment on the impact of CSR on competitiveness).

Based on the above, it can be concluded that setting the concept of social responsibility and sustainable development in organizations is a current and discussed topic, not least because past and present developments, which are based primarily on economic growth, irreversibly affect the form and functioning of landscapes and entire planets. Therefore, it is necessary to deal with the possibilities of eliminating or mitigating the negative manifestations of the current way of development of human society, whether for individuals or organizations themselves and to apply this in the concept of CSR.

Most natural resources are finite and it is necessary to control their over-exploitation in some way. The word sustainability should become a priority for every organization, and each of its employees should be made aware of this direction and identified with it. It is necessary to realize that for the continued existence it is not possible to take into account not only economic growth but also social values and natural resources sustainability tends to do so. Each organization and its employees should address the quality of life and meet the needs of the present generation without compromising the needs of future generations and other people. The social, environmental, and economic pillars of society are closely linked, and that one of them cannot be given priority over the others.

The article aims to identify the approaches of Czech business entities to the promotion of the concept of social responsibility in selected organizations $(n=179)$. The article contains six logically connected parts. The first part describes the topicality, importance, and theoretical background of the article, followed by the research methodology and an analytical part with annotated results of advanced statistical analyzes, followed by a discussion and conclusion with a summary of key survey results.

\section{Methodology}

The research is focused on identifying the approaches of organizations to sustainable development in selected organizations. The quantitative data was obtained by a questionnaire survey in Czech organizations (quota-based selection). A total of $n=179$ organizations participated in the survey. The survey occurred from 06/2020 to 12/2020. The results can only be generalized for the research sample. The sample was based on the ALBERTINA database of organizations (which contains important data of more than 2,700,000 organizations registered in the Czech Republic). The questionnaire was distributed to companies by e-mail, 850 companies were contacted twice (with a reminder), the rate of return of the questionnaire is $21 \%$. The basic identifying features of the questionnaire survey include: size of the organization, sector of operation of the organization (primary, secondary, tertiary), type of organization (for-profit, non-profit), and majority ownership. 
The questionnaire was completed by mid-tier or higher management of the organization, in case of smaller organizations by the owner itself (thus the responses reflected the point view of their heads/owner/manager).

Dependencies between selected qualitative features were tested. To test the hypothesis of homogeneity and independence, chi-square tests with $(r-1)(s-1)$ degrees of freedom were applied:

$$
\chi^{2}=\sum_{i=1}^{r} \sum_{j=1}^{S} \frac{\left(n_{i j}-m_{i j}\right)^{2}}{m_{i j}}
$$

where:

$n_{i j}$ - observed frequency,

$m_{i j}$ - excepted frequency.

The results were analyzed using statistical tools - the dependence test $(\chi 2)$ and the power of dependence test (Cramer's $V$ ). The chi-square tests are used to test the hypothesis of homogeneity and independence, rejecting / rejecting the null hypothesis of dependence or homogeneity at a given level of significance $\alpha=0.05$. Good approximation requirements were always met in the computations, if theoretical frequencies were larger than or equal to 5 in $80 \%$ of instances, and never dropped below 2 even in the remaining $20 \%$. The dependence strength was calculated using the Cramer's $V$ measure, that is within $0 \leq V \leq 1$.

The questionnaire was designed to comply with ethical rules and with the requirement for anonymity, and contained 60 questions. Within this article, 3 questions and 4 identification questions were evaluated with multiple answer options.

The questions were close-ended (allowing only provided response options) and with more response options. The structure of the organizations, participating in the research $(n=179)$, was as follows (see Table 1$)$.

Table 1. Organizations that participated in the research - basic data

\begin{tabular}{|c|c|c|c|}
\hline Characteristics & \multicolumn{3}{|c|}{ Categories } \\
\hline \multirow{2}{*}{ Sector } & Primary & Secondary & Tertiary \\
\hline & $4.5 \%$ & $40.2 \%$ & $55.3 \%$ \\
\hline \multirow{2}{*}{ Type of organization } & Private & Public & Non-profit \\
\hline & $86.0 \%$ & $11.2 \%$ & $2.8 \%$ \\
\hline \multirow[t]{2}{*}{ Turnover } & $<10$ mil. EUR & 11-50 mil. EUR & $\begin{array}{c}>50 \mathrm{mil} \\
\text { EUR }\end{array}$ \\
\hline & $38.5 \%$ & $38.0 \%$ & $23.5 \%$ \\
\hline \multirow{2}{*}{ Type of organization in terms of majority ownership } & Domestic & \multicolumn{2}{|c|}{ Foreign } \\
\hline & $45.3 \%$ & \multicolumn{2}{|c|}{$54.7 \%$} \\
\hline \multirow{2}{*}{ The size of the organization (number of employees and \%) } & $<50$ & 51-249 & $>\mathbf{2 5 0}$ \\
\hline & $26.8 \%$ & $27.9 \%$ & $45.3 \%$ \\
\hline \multirow[t]{2}{*}{ Organization focus } & Business activity & $\begin{array}{c}\text { Provision of } \\
\text { services }\end{array}$ & Production \\
\hline & $18.4 \%$ & $40.8 \%$ & $40.8 \%$ \\
\hline
\end{tabular}

Table 1 shows that the research focused mainly on private organizations, $11.2 \%$ represents the share of public organizations, and only less than $3 \%$ of non-profit organizations. Most organizations have a foreign shareholding (54.7\%) and employ more 
than 250 employees (45.3\%). In terms of the focus of organizations, it can be stated that $40.8 \%$ are services, the same part of production and business activities from the examined sample of respondents occupies $18.4 \%$. The IBM SPSS Statistics 24 statistical software was used to evaluate the results (Bryman et al., 2011; Verma, 2012; Gunarto, 2019).

\section{Results}

Based on the evaluation of the results, it can be stated that the addressed organizations focus mainly on their economic, environmental, and social aspects and impacts in all processes and projects within their business activities (see Table 2).

Table 2. The organization's focus on CSR and sustainability

\begin{tabular}{|c|c|c|}
\hline Organization's focus & $\begin{array}{l}\text { Absolute } \\
\text { frequency }\end{array}$ & $\begin{array}{c}\text { Relative } \\
\text { frequency } \\
(\%)\end{array}$ \\
\hline $\begin{array}{l}\text { A. Organization's focus - economic and environmental } \\
\text { Within business activities, the main emphasis is placed } \\
\text { on economic and environmental goals. In the social field, } \\
\text { compliance with relevant laws is achieved }\end{array}$ & 16 & 8.9 \\
\hline $\begin{array}{l}\text { B. Organization's focus - economic and social } \\
\text { Within business activities, the main emphasis is placed } \\
\text { on economic and social goals. The company's approach } \\
\text { to the environment is in accordance with environmental } \\
\text { protection laws }\end{array}$ & 48 & 26.8 \\
\hline $\begin{array}{l}\text { C. Organization's focus - economic } \\
\text { Within business activities, the main emphasis is placed } \\
\text { on economic goals (i.e. long-term profit making). In the } \\
\text { social area and in the area of access to the environment, } \\
\text { compliance with applicable laws is achieved }\end{array}$ & 41 & 22.9 \\
\hline $\begin{array}{l}\text { D. Organization's focus - economic, environmental, } \\
\text { and social } \\
\text { Within business activities, all processes and projects are } \\
\text { assessed with regard to their economic, environmental } \\
\text { and social aspects and impacts }\end{array}$ & 74 & 41.3 \\
\hline Total & 179 & 100.0 \\
\hline
\end{tabular}

The results are positive, as most of the examined organizations emphasize not only the economic side of individual goals but also the social and environmental area. The social, environmental, and economic pillars of society are closely linked and it is not possible for the organization to prioritize any of them at the expense of others. Respondents were also able to rate the specific characteristics of the organization in the field of CSR and sustainability (see Table 3 ) on a scale of 1 (strongly agree) to 4 (strongly disagree).

Most organizations stated that they have only partially incorporated sustainable development into their corporate strategy (level 2) at $49.2 \%$. Only $1.3 \%$ of the addressed organizations do not include this area in the strategy. At level 2 out of 4, most respondents were in all answers, i.e. within the use of voluntary tools beyond the law (41.3\%), attention to social entrepreneurship and health and safety (45.8\%) and CSR profiling (35.8\%) or compliance with laws in this area (38\%). However, regarding the characteristics of the organization in the CSR approach leading to competitive advantage, the respondents were in favor of the fact that these characteristics do not have a direct impact on the 
Table 3. Characteristics of the organization in the approach to CSR

\begin{tabular}{|l|c|c|c|c|}
\hline \multicolumn{1}{|c|}{ Characteristics of the organization } & Minimum & Maximum & Mean & $\begin{array}{c}\text { Std. } \\
\text { Deviation }\end{array}$ \\
\hline $\begin{array}{l}\text { Sustainable development is incorporated into the } \\
\text { company's strategy }\end{array}$ & 1 & 4 & 1.85 & 0.735 \\
\hline $\begin{array}{l}\text { Voluntary tools and approaches (beyond the law) } \\
\text { aimed at environmental protection and pollution } \\
\text { prevention are used }\end{array}$ & 1 & 4 & 2.21 & 0.893 \\
\hline $\begin{array}{l}\text { We pay great attention to the social aspects of business } \\
\text { (beyond the law), especially the issue of safety and } \\
\text { health at work and relations with the company's } \\
\text { environment and other important stakeholders }\end{array}$ & 1 & 4 & 1.82 & 0.760 \\
\hline $\begin{array}{l}\text { We profile ourselves as a socially responsible } \\
\text { company; we implement projects focused on } \\
\text { environmental protection, projects beneficial to } \\
\text { employees, the local location, or other relevant } \\
\text { stakeholders }\end{array}$ & 1 & 4 & 2.12 & 0.922 \\
\hline $\begin{array}{l}\text { The concept of sustainable development is a matter for } \\
\text { the state }\end{array}$ & 1 & 4 & 2.40 & 0.884 \\
\hline
\end{tabular}

Table 4. Characteristics of the organization in the approach to CSR lead to a competitive advantage.

\begin{tabular}{|l|c|c|c|c|}
\hline \multicolumn{1}{|c|}{ Characteristics of the organization } & Minimum & Maximum & Mean & $\begin{array}{c}\text { Std. } \\
\text { Deviation }\end{array}$ \\
\hline Involvement in the supply chain & 1 & 4 & 3.04 & 0.905 \\
\hline Innovation activities & 1 & 4 & 3.40 & 0.691 \\
\hline $\begin{array}{l}\text { Productivity (valuation of inputs, use of production } \\
\text { factors) }\end{array}$ & 1 & 4 & 3.47 & 0.698 \\
\hline Differentiation from the competition & 1 & 4 & 3.49 & 0.752 \\
\hline Reputation (good name), brand & 1 & 4 & 3.69 & 0.664 \\
\hline Attractiveness of the company as an employer & 1 & 4 & 3.41 & 0.755 \\
\hline Market share & 1 & 4 & 3.20 & 0.828 \\
\hline Company communication (internal and external) & 1 & 4 & 3.46 & 0.751 \\
\hline Creating value for the customer & 1 & 4 & 3.14 & 0.740 \\
\hline $\begin{array}{l}\text { The willingness of the customer to pay for the high } \\
\text { perceived value of the products }\end{array}$ & 1 & 4 & 3.29 & 0.838 \\
\hline Payment morale of the company & 1 & 4 & 3.49 & 0.737 \\
\hline Ability to generate profits (long term) & 4 & 2.99 & 0.768 \\
\hline Impact of government measures & 4 & 3.19 & 0.733 \\
\hline Human resources competence & 1 & 430 \\
\hline
\end{tabular}

achievement of competitive advantage. However, they are heavily influenced by government measures (see Table 4).

Furthermore, the dependencies between selected qualitative features were tested, hypotheses were tested:

- $\mathrm{H}_{0} 1$ : The focus of the organization in terms of a three-pillar CSR system does not depend on the business sector. 
- $\mathrm{H}_{02}$ : The focus of the organization in terms of a three-pillar CSR system does not depend on the size of the organization.

- Ho3: The focus of the organization in terms of a three-pillar CSR system does not depend on the majority ownership of the organization.

- Ho4: The focus of the organization in terms of a three-pillar CSR system does not depend on the type of the organization.

Table 5. Pivot table of organizations focusing on CSR by sector.

\begin{tabular}{|l|c|c|c|c|}
\hline \multicolumn{2}{|c|}{} & \multicolumn{2}{|c|}{ Sector } & \\
\cline { 2 - 5 } Organization's focus & $\begin{array}{c}\text { Primary } \\
\text { (agriculture, } \\
\text { forestry and } \\
\text { fishing) }\end{array}$ & $\begin{array}{c}\text { Secondary } \\
\text { (manufacturing) }\end{array}$ & $\begin{array}{c}\text { Tertiary } \\
\text { (services) }\end{array}$ & Total \\
\hline $\begin{array}{l}\text { A. Organization's focus: economic, and } \\
\text { environmental }\end{array}$ & 0 & 6 & 10 & $\mathbf{1 6}$ \\
\hline $\begin{array}{l}\text { B. Organization's focus: economic, and social } \\
\text { C. Organization's focus: economic focus: economic, }\end{array}$ & 4 & 18 & 26 & $\mathbf{4 8}$ \\
\hline $\begin{array}{l}\text { D. Organization's } \\
\text { environmental, and social }\end{array}$ & 0 & 13 & 28 & $\mathbf{4 1}$ \\
\hline Total & $\mathbf{8}$ & $\mathbf{7 2}$ & $\mathbf{9 9}$ & $\mathbf{7 4}$ \\
\hline
\end{tabular}

Table 6. Pivot table of organizations focusing on CSR according to the size of the organization.

\begin{tabular}{|l|c|c|c|c|}
\hline \multicolumn{1}{|c|}{ Organization's focus } & \multicolumn{2}{c|}{$\begin{array}{c}\text { Size of the organization (number } \\
\text { of employees) }\end{array}$} \\
\cline { 2 - 4 } & $>\mathbf{2 5 0}$ & $\mathbf{5 1 - 2 4 9}$ & $<\mathbf{5 0}$ \\
\hline A. Organization's focus: economic, and environmental & 7 & 5 & 4 & $\mathbf{1 6}$ \\
\hline B. Organization's focus: economic, and social & 19 & 18 & 11 & $\mathbf{4 8}$ \\
\hline C. Organization's focus: economic & 17 & 7 & 17 & $\mathbf{4 1}$ \\
\hline D. Organization's focus: economic, environmental, and social & 38 & 20 & 16 & $\mathbf{7 4}$ \\
\hline Total & $\mathbf{8 1}$ & $\mathbf{5 0}$ & $\mathbf{4 8}$ & $\mathbf{1 7 9}$ \\
\hline
\end{tabular}

Table 7. Contingency table of organizations focusing on CSR according to majority ownership and type of organization.

\begin{tabular}{|c|c|c|c|c|c|c|}
\hline \multirow[b]{2}{*}{ Organization's focus } & \multicolumn{2}{|c|}{ Majority ownership } & \multicolumn{3}{|c|}{ Type of organization } & \multirow[b]{2}{*}{ Total } \\
\hline & Domestic & Foreign & $\begin{array}{l}\text { Non- } \\
\text { profit }\end{array}$ & Private & Public & \\
\hline $\begin{array}{l}\text { A. Organization's focus: economic, } \\
\text { and environmental }\end{array}$ & 10 & 6 & 2 & 11 & 3 & 16 \\
\hline $\begin{array}{l}\text { B. Organization's focus: economic, } \\
\text { and social }\end{array}$ & 20 & 28 & 1 & 43 & 4 & 48 \\
\hline C. Organization's focus: economic & 19 & 22 & 0 & 36 & 5 & 41 \\
\hline $\begin{array}{l}\text { D. Organization's focus: economic, } \\
\text { environmental, and social }\end{array}$ & 32 & 42 & 2 & 64 & 8 & 74 \\
\hline Total & 81 & 98 & 5 & 154 & 20 & 179 \\
\hline
\end{tabular}


The dependencies of the PivotTables are listed in Tables 5-7. Table 5 shows that the largest share of organizations that deal with CSR and the environmental aspect, including economical aspect, are companies in the primary sector (agriculture, forestry, and food). Furthermore, in the secondary sector and subsequently in the tertiary sector. According to size, these are primarily larger companies with a set CSR strategy and sustainability (see Table 6).

Furthermore, these are organizations with a foreign majority share in the private sector (see Table 7).

Based on the performed testing, it can be summarized that the null hypotheses were confirmed:

- $\mathrm{H}_{0} 1$ : The focus of the organization in terms of a three-pillar CSR system does not depend on the business sector ( $p$-value $=0.214$ ).

- Ho2: The focus of the organization in terms of a three-pillar CSR system does not depend on the size of the organization ( $p$-value $=0.186$ ).

- Ho3: The focus of the organization in terms of a three-pillar CSR system does not depend on the majority ownership of the organization ( $p$-value $=0.511)$.

- Ho4: The focus of the organization in terms of a three-pillar CSR system does not depend on the type of the organization ( $p$-value $=0.204)$.

The approach of business entities to the promotion of the concept of social responsibility does not affect the sector, size, type or ownership share of the organization.

The concept of CSR must be applied in organizations at the highest level, i.e. strategic management, and must be supported by top management. CSR leads organizations to responsible and sustainable business and is currently indispensable against the classic focus on short-term or long-term profit or prosperity and risk-free operations with a close link to the company's economic goals. Now, organizations are increasingly exposed to greater oversight by all interest groups that affect or are affected by the organization's operations. Therefore, it is necessary to focus all more on environmental and social local and global CSR challenges such as transparency, ethics, anti-corruption strategies, human rights, climate change, supply chain responsibility, or tax transparency in all types of organizations, regardless of sector, size, focus or majority share.

\section{Discussion}

Responsible business is becoming an increasingly important topic in the debate on globalization, competitiveness, and sustainable development (Kolk \& Van Tulder, 2010; Bansal et al., 2015; Fortunati et al., 2020). Responsible business is important for people working in companies and for companies that can help them create a work environment. At the same time, it is important for those who buy from businesses for consumers, who are paying increasingly attention to the social or environmental nature of the products and services they buy (Sarkar \& Searcy, 2016). It is important for local communities (Newell, 2005) to know that they live among organizations that share their values and concerns. It is also important for investors (Verbeeten et al., 2016) who feel the need to promote responsible 
corporate behavior, but also for people from other parts of the world who expect European companies to behave in accordance with European and international values and principles. At present, by opening up the market, customers / citizens (Martínez \& Del Bosque, 2013) perceive the market more complex and are interested in products and services from companies whose goals are not only economic, but also social and environmental. This is a challenge for small and medium-sized organizations.

\section{Conclusions}

Responsible business is a concept in which companies voluntarily incorporate social and environmental aspects into their business operations and stakeholder relationships. It is therefore the overall relationship of the organization with all stakeholders - customers, owners-investors, employees, public authorities, suppliers, competitors, communities, etc. It includes the organization's commitment to develop its economic activities effectively and responsibly to society and the environment, taking into account the interests of all stakeholders' entities. Each stakeholder in a way affects the competitiveness of the organization. Owners and shareholders are interested in the growth and prosperity of the organization, employees evaluate working conditions, customers are interested in the quality of products and services, the government is interested in reducing unemployment and creating suitable business conditions, and citizens are interested in the behavior of organizations in their place of operation. The results showed that the surveyed organizations are more concerned with the concept of CSR and sustainability, although they do not see a direct impact on the competitiveness of the organization. However, they consider this area to be important and impossible to ignore in the future.

\section{References}

Ahi, P., \& Searcy, C. (2013). A comparative literature analysis of definitions for green and sustainable supply chain management. Journal of cleaner production, 52, 329-341. https://doi.org/10.1016/j.jclepro.2013.02.018

Ali, I., Rehman, K. U., Yilmaz, A. K., Nazir, S., \& Ali, J. F. (2010). Effects of corporate social responsibility on consumer retention in the cellular industry of Pakistan. African Journal of Business Management, 4(4), 475485.

Bansal, P., Jiang, G. F., \& Jung, J. C. (2015). Managing responsibly in tough economic times: strategic and tactical CSR during the 2008-2009 global recession. Long Range Planning, 48(2), 69-79. https://doi.org/10.1016/j.lrp.2014.07.002

Bernal-Conesa, J. A., de Nieves Nieto, C., \& Briones-Peñalver, A. J. (2017). CSR strategy in technology companies: Its influence on performance, competitiveness and sustainability. Corporate social responsibility and environmental management, 24(2), 96-107. https://doi.org/10.1002/csr.1393

Boulouta, I., \& Pitelis, C. N. (2014). Who needs CSR? The impact of corporate social responsibility on national competitiveness. Journal of business ethics, 119(3), 349-364. https://doi.org/10.1007/s10551-013-1633-2

Bryman, A., \& Cramer, D. (2011). Quantitative data analysis with IBM SPSS 17, 18 and 19. Routledge, New York.

Burke, L., \& Logsdon, J. M. (1996). How corporate social responsibility pays off. Long range planning, 29(4), 495502. https://doi.org/10.1016/0024-6301(96)00041-6

Camacho, J., \& Fernandez, J. L. (2018). Competitiveness and CSR in SME: Results from a Study in the Madrid Region. Management Dynamics in the Knowledge Economy, 6(1), 105-116. https://doi.org/10.25019/mdke/6.1.06

Cancino, C. A., La Paz, A. I., Ramaprasad, A., \& Syn, T. (2018). Technological innovation for sustainable growth: An ontological perspective. Journal of Cleaner Production, 179, 31-41.

https://doi.org/10.1016/j.jclepro.2018.01.059 
Charitoudi, G., Sariannidis, N., \& Giannarakis, G. (2011). The development guide for corporate social responsibility programming. European Journal of Scientific Research, 65(1), 20-27.

Ciccullo, F., Pero, M., Caridi, M., Gosling, J., \& Purvis, L. (2018). Integrating the environmental and social sustainability pillars into the lean and agile supply chain management paradigms: A literature review and future research directions. Journal of Cleaner Production, 172, 2336-2350. https://doi.org/10.1016/j.jclepro.2017.11.176

Dahlsrud, A. (2008). How corporate social responsibility is defined: an analysis of 37 definitions. Corporate social responsibility and environmental management, 15(1), 1-13. https://doi.org/10.1002/csr.132

EU. (2001). Promoting a European framework for corporate social responsibility. Retrieved December 19, 2020, from https://www.jussemper.org/Resources/Corporate\%20Activity/Resources/greenpaper_en.pdf

European Commission. (2011). Communication from the Commission to the European Parliament, the Council, the European Economic and Social Committee and the Committee of the Regions Youth Opportunities Initiative.

Fortunati, S., Morea, D., \& Mosconi, E. M. (2020). Circular economy and corporate social responsibility in the agricultural system: Cases study of the Italian agri-food industry. Agricultural Economics, 66, 489-498. https://doi.org/10.17221/343/2020-AGRICECON

Gallardo-Vázquez, D., \& Sanchez-Hernandez, M. I. (2014). Measuring Corporate Social Responsibility for competitive success at a regional level. Journal of Cleaner Production, 72, 14-22. https://doi.org/10.1016/j.jclepro.2014.02.051

Gond, J. P., \& Moon, J. (2011). Corporate social responsibility in retrospect and prospect: Exploring the life-cycle of an essentially contested concept. ICCSR Research Paper Series, 59, 1-40.

Gunarto, H. (2019). Parametric and Nonparametric Data Analysis for Social Research: IBM SPSS. LAP LAMBERT Academic Publishing, Beau-Bassin, Mauritius.

Hung, S., Li, C., \& Lee, J. (2019). Firm growth, business risk, and corporate social responsibility in Taiwan's food industry. Agricultural Economics, 65, 366-374. https://doi.org/10.17221/339/2018-AGRICECON

Jenkins, H. (2009). A business opportunity model of corporate social responsibility for small and medium-sized enterprises. Business Ethics: A European Review, 18(1), 21-36. https://doi.org/10.1111/j.1467-8608.2009.01546.x

Jorge, M. L., Madueño, J. H., Martinez-Martinez, D., \& Sancho, M. P. L. (2015). Competitiveness and environmental performance in Spanish small and medium enterprises: is there a direct link? Journal of cleaner production, 101, 26-37. https://doi.org/10.1016/j.jclepro.2015.04.016

Kolk, A., \& Van Tulder, R. (2010). International business, corporate social responsibility and sustainable development. International business review, 19(2), 119-125. https://doi.org/10.1016/j.ibusrev.2009.12.003

Mandl, I., \& Dorr, A. (2007). CSR and competitiveness-European SMEs' good practice. Consolidated European Report, Vienna: Austrian Institute for SME Research.

Marin, L., Martín, P. J., \& Rubio, A. (2017). Doing good and different! The mediation effect of innovation and investment on the influence of CSR on competitiveness. Corporate social responsibility and environmental management, 24(2), 159-171. https://doi.org/10.1002/csr.1412

Marín, L., Rubio, A., \& de Maya, S. R. (2012). Competitiveness as a strategic outcome of corporate social responsibility. Corporate social responsibility and environmental management, 19(6), 364-376. https://doi.org/10.1002/csr.1288

Martínez, P., \& Del Bosque, I. R. (2013). CSR and customer loyalty: The roles of trust, customer identification with the company and satisfaction. International Journal of Hospitality Management, 35, 89-99. https://doi.org/10.1016/j.ijhm.2013.05.009

Newell, P. (2005). Citizenship, accountability and community: the limits of the CSR agenda. International affairs, 81(3), 541-557. https://doi.org/10.1111/j.1468-2346.2005.00468.x

Petříček, M., Chalupa, S., \& Chadt, K. (2020). Identification of Consumer Behavior Based on Price Elasticity: A Case Study of the Prague Market of Accommodation Services. Sustainability, 22(12), 1-14. https://doi.org/10.3390/su12229452

Porter, M. E., \& Kramer, M. (2006). Strategy and society: The link between competitive advantage and corporate social responsibility. Harvard Business Review, 84(12), 78-92. https://doi.org/10.1108/sd.2007.05623ead.006

Sarkar, S., \& Searcy, C. (2016). Zeitgeist or chameleon? A quantitative analysis of CSR definitions. Journal of Cleaner Production, 135, 1423-1435. https://doi.org/10.1016/j.jclepro.2016.06.157

Schiebel, W., \& Pöchtrager, D. (2003). Corporate ethics as a factor for success - the measurement instrument of the University of Agricultural Sciences (BOKU), Vienna. Supply Chain Management, 8(2), 116-121.

https://doi.org/10.1108/13598540310468715 
Turyakira, P., Venter, E., \& Smith, E. (2014). The impact of corporate social responsibility factors on the competitiveness of small and medium-sized enterprises. South African Journal of Economic and Management Sciences, 17(2), 157-172. https://doi.org/10.4102/sajems.v17i2.443

Van Marrewijk, M. (2003). Concepts and definitions of CSR and corporate sustainability: Between agency and communion. Journal of business ethics, 44(2-3), 95-105. https://doi.org/10.1023/A:1023331212247

Verbeeten, F. H., Gamerschlag, R., \& Möller, K. (2016). Are CSR disclosures relevant for investors? Empirical evidence from Germany. Management Decision. https://doi.org/10.1108/MD-08-2015-0345

Verma, J. P. (2012). Data analysis in management with SPSS software. Springer Science \& Business Media.

Vilanova, M., Lozano, J. M., \& Arenas, D. (2009). Exploring the nature of the relationship between CSR and competitiveness. Journal of business Ethics, 87(1), 57-69. https://doi.org/10.1007/s10551-008-9812-2

Yadlapalli, A., Rahman, S., \& Gunasekaran, A. (2020). Corporate social responsibility definitions in supply chain research: An ontological analysis. Journal of Cleaner Production, 277, 123265.

https://doi.org/10.1016/j.jclepro.2020.123265 